\title{
AGRICULTURAL CLIMATE RISK ZONING FOR GLADIOLUS IN SANTA CATARINA
}

BONATTO, Melina Inês - melina.bonatto@gmail.com Universidade Federal de Santa Catarina / UFSC

BOSCO, Leosane Cristina -leosane.bosco@ufsc.br Universidade Federal de Santa Catarina / UFSC

PANDOLFO, Cristina - cristina@epagri.sc.gov.br Empresa de Pesquisa Agropecuária e Extensão Rural de Santa Catarina / EPAGRI

RICCE, Wilian da Silva - wilianricce@epagri.sc.gov.br Empresa de Pesquisa Agropecuária e Extensão Rural de Santa Catarina / EPAGRI

STANCK, Luciane Teixeira - lucianestanck@yahoo.com.br Universidade Federal de Santa Catarina / UFSC

SOUZA, Alexandra Goede de - alexandra.souza@ifc.edu.br Instituto Federal de Santa Catarina / IFSC

ROSSATO, Otavio Bagiotto - otavio.rossato@ifc.edu.br Instituto Federal de Santa Catarina / IFSC

STRECK, Nereu Augusto - nstreck2@yahoo.com.br Universidade Federal de Santa Maria / UFSM

Submetido em: 24/04/2020 Aceito para publicação em: 14/05/2021 Publicado em: 01/06/2021 DOI: http://dx.doi.org/10.5380/abclima.v28i0.73149

\begin{abstract}
This work aims to developing an Agricultural Climate Risk Zoning for gladiolus in the State of Santa Catarina. The bioclimatic requirements and the risk criteria were defined for the crop through a bibliographic review. The probability of frost occurrence, water balance and frequency of maximum air temperatures above $34^{\circ} \mathrm{C}$ were calculated with meteorological database. A maximum assumed risk of $20 \%$ was considered. The period when planting is not recommended was determined for each of the development cycles (early, intermediate I and II and late). It was observed that low temperatures and occurrence of frost in autumn and winter limits gladiolus planting in the State of Santa Catarina. Analysis of the water balance indicated there is risk of water deficiency throughout the year, which varies according to the locations. Maximum air temperatures above $34^{\circ} \mathrm{C}$ do not occur frequently in the State. In the Coastal regions, there are no restrictions to planting throughout the year. The Agricultural Climate Risk Zoning indicate the potential for gladiolus farming in Santa Catarina, where the greatest planting potential is in the Coastal, West and Extreme West regions.
\end{abstract}

KEYWORDS: Gladiolus x grandiflorus; Agricultural planning; Frost; High temperature; Water deficiency.

ZONEAMENTO AGRÍCOLA DE RISCO CLIMÁTICO PARA GLADÍOLO EM SANTA CATARINA

RESUMO: Este trabalho tem como objetivo desenvolver um Zoneamento Agrícola de Risco Climático para gladíolo no Estado de Santa Catarina. Os requisitos bioclimáticos e 
os critérios de risco foram definidos para a cultura através de revisão bibliográfica. A probabilidade de ocorrência de geadas, balanço hídrico e frequência de temperaturas máximas do ar acima de $34^{\circ} \mathrm{C}$ foram calculadas com banco de dados meteorológicos. $\mathrm{O}$ risco máximo assumido foi de $20 \%$. O período em que o plantio não é recomendado foi determinado para cada um dos ciclos de desenvolvimento (precoce, intermediário I e II e tardio). Observou-se que baixas temperaturas e ocorrência de geadas no outono e inverno limitam o plantio de gladíolo no estado de Santa Catarina. A análise do balanço hídrico indicou que há risco de deficiência de água ao longo do ano, que varia de acordo com os locais. Temperaturas máximas do ar acima de $34^{\circ} \mathrm{C}$ não ocorrem com frequência no Estado. Nas regiões costeiras, não há restrições ao plantio ao longo do ano. 0 Zoneamento Agrícola de Risco Climático indica o potencial para o cultivo de gladíolo em Santa Catarina, onde o maior potencial de plantio está nas regiões Costeira, Oeste e Extremo Oeste.

PALAVRAS-CHAVE: Gladiolus $x$ grandiflorus; Planejamento agrícola; Geada; Altas temperaturas; Deficiência hídrica.

\section{ZONIFICACIÓN AGRÍCOLA DEL RIESGO CLIMÁTICO PARA GLADIOLOS EN SANTA CATARINA}

RESUMEN: Este trabajo tiene como objetivo desarrollar una zonificación de riesgo climático agrícola para gladiolos en la província de Santa Catarina. Los requisitos bioclimáticos y los criterios de riesgo se definieron para el cultivo a través de una revisión de la literatura. La probabilidad de aparición de heladas, el balance hídrico y la frecuencia de temperaturas máximas del aire superiores a $34^{\circ} \mathrm{C}$ se calcularon utilizando una base de datos meteorológicos. El riesgo máximo asumido fue del $20 \%$. El período en el que no se recomienda la siembra se determinó para cada uno de los ciclos de desarrollo (temprano, intermedio I y II y tardío). Se observó que las bajas temperaturas y la aparición de heladas en otoño e invierno limitan la siembra de gladiolos en la província de Santa Catarina. El análisis del balance hídrico indicó que existe un riesgo de deficiencia de agua durante todo el año, que varía según las ubicaciones. Las temperaturas máximas del aire por encima de $34^{\circ} \mathrm{C}$ no ocurren con frecuencia en el estado. En las regiones costeras, no hay restricciones para plantar durante todo el año. La zonificación agrícola del riesgo climático indica el potencial para el cultivo de gladiolos en Santa Catarina, donde el mayor potencial de siembra se encuentra en las regiones costeras, occidentales y lejanas.

PALABRAS CLAVE: Gladiolus $x$ grandiflorus; Planificación agrícola; Heladas; Altas temperaturas; Deficiencia de agua.

\section{INTRODUCTION}

Gladiolus (Gladiolus $x$ grandiflorus Hort.), also known as Palma-deSanta-Rita or palm, is among the most important cut flowers in Brazil. Gladiolus is propagated through corms and cormlets. The corms go to cut flower production, while the cormlets are grown to produce new corms (SCHWAB et al., 2019).

Gladiolus cultivars differ by both the color of the floral stem and by the length of the flowering cycle. Early cultivars have short flowering cycles, from 65 to 87 days after planting (DAP), whereas late cultivars bloom from 85 to 120 DAP (BOYLE et al., 2009, SCHWAB et al., 2019). Given that cycle duration is influenced by air temperature, the variation depends on the time of year planting takes place. If temperatures are high, without stress, plants have more energy available to grow and develop, reducing cycle duration (STRECK et al., 2012; SCHWAB et al., 2018).

Due to its rusticity, gladiolus adapts well to different types of soils. However, cultivation in poorly drained soils should be avoided due to the risk of 
rot disease (SCHWAB et al., 2019). Gladiolus vegetative and reproductive development is influenced by weather conditions. It develops well at average air temperatures of 10 to $25^{\circ} \mathrm{C}$ (LIM, 2014), is not frost-tolerant, and its most critical phase is the reproductive phase (LIM, 2014, SCHWAB et al., 2018).

To achieve economic productivity, it is important to properly assess the region's environmental conditions before implementing any agricultural activity. In this context, Climate Risk Zoning is an important tool that can be used in agricultural planning to reduce risks and consequently, improve the yield and quality of agriculture products (EMBRAPA, 2015). It is also essential to subsidize agricultural policies and decrease the seasonality of cultivated products.

The zoning for gladiolus has already been developed for the State of Rio Grande do Sul (BECKER et al., 2020) and is assisting producers and technicians in recommending new cultivation areas, with an improvement in the quality of flower stems and aggregation of value and profit on the farm (UHLMANN et al., 2019). So, we hypothesize the same social and economic effects of a gladiolus zoning for the state of Santa Catarina, and due to this we had as objective to develop an Agricultural Climate Risk Zoning for gladiolus in this state.

\section{MATERIAL AND METHODS}

Santa Catarina is a Brazilian state, located in the center of the Southern region of Brazil with a territorial area of $95,737 \mathrm{~km}^{2}$ and divided into 295 municipalities. According to the Köppen climate classification, the State has an area of $40.1 \%$ with Cfa climate and $59.9 \%$ with Cfb climate (ALVARES et al., 2013). Santa Catarina regions considered in this study was South Plateau, North Plateau, Mountain Plateau, Itajaí Valley, Midwest, West, Extreme Oeste and Coastal (Table 1).

Table 1 - Latitude, longitude and altitude (Alt, m) of meteorological stations that constitute the Epagri/Ciram Meteorological Database (1985-2014) used to calculate the climatic risk factors for Santa Catarina.

\begin{tabular}{lcccc}
\hline Region & Municipality/Code & Latitude & Longitude & Alt \\
\hline Midwest & Caçador/60 & $-26^{\circ} 49^{\prime} 10^{\prime \prime}$ & $-50^{\circ} 59^{\prime} 09^{\prime \prime}$ & 960 \\
South Plateau & Campos Novos/469 & $-27^{\circ} 23^{\prime} 01^{\prime \prime}$ & $-51^{\circ} 12^{\prime} 58^{\prime \prime}$ & 965 \\
West & Chapecó / 108 & $-27^{\circ} 05^{\prime} 27^{\prime \prime}$ & $-52^{\circ} 38^{\prime} 03^{\prime \prime}$ & 679 \\
Coastal & Indaial/ 67 & $-26^{\circ} 54^{\prime} 51^{\prime \prime}$ & $-49^{\circ} 16^{\prime} 06^{\prime \prime}$ & 86 \\
Coastal & Itajaí/183 & $-26^{\circ} 57^{\prime} 05^{\prime \prime}$ & $-48^{\circ} 45^{\prime} 45^{\prime \prime}$ & 5 \\
Extreme West & Itapiranga/477 & $-27^{\circ} 10^{\prime} 05^{\prime \prime}$ & $-53^{\circ} 38^{\prime} 44^{\prime \prime}$ & 200 \\
Itajaí Valley & Ituporanga/191 & $-27^{\circ} 25^{\prime} 08^{\prime \prime}$ & $-49^{\circ} 38^{\prime} 47^{\prime \prime}$ & 475 \\
Mountain Plateau & Lages/230 & $-27^{\circ} 48^{\prime} 31^{\prime \prime}$ & $-50^{\circ} 19^{\prime} 48^{\prime \prime}$ & 937 \\
North Plateau & Major Vieira/515 & $-26^{\circ} 21^{\prime} 54^{\prime \prime}$ & $-50^{\circ} 20^{\prime} 14^{\prime \prime}$ & 765 \\
Mountain Plateau & São Joaquim/353 & $-28^{\circ} 16^{\prime} 33^{\prime \prime}$ & $-49^{\circ} 56^{\prime} 06^{\prime \prime}$ & 1376 \\
Coastal & São José/124 & $-27^{\circ} 21^{\prime} 40^{\prime \prime}$ & $-48^{\circ} 22^{\prime} 17^{\prime \prime}$ & 2 \\
Extreme West & São Miguel do Oeste/361 & $-26^{\circ} 46^{\prime} 35^{\prime \prime}$ & $-53^{\circ} 30^{\prime} 15^{\prime \prime}$ & 700 \\
South & Urussanga/434 & $-28^{\circ} 31^{\prime} 56^{\prime \prime}$ & $-49^{\circ} 18^{\prime} 54^{\prime \prime}$ & 48 \\
Midwest & Videira/442 & $-27^{\circ} 01^{\prime} 30^{\prime \prime}$ & $-51^{\circ} 09^{\prime} 00^{\prime \prime}$ & 774 \\
\hline
\end{tabular}

It was possible to identify the bioclimatic requirements of the gladiolus crop through a literature review and experiments carried out in the State of Santa Catarina from 2015 to 2019. The main identified risks to the crop are related to frost, water deficit and high temperatures. The maximum risk assumed was $20 \%$, in accordance with the Ministry of Agriculture, Livestock and Supply' methodology (MAPA, 2019). Thus, the minimum and maximum air 
temperatures and water balance were the analyzed factors. The climate risk inferences were applied to the four development cycles (early, intermediate I and II and late) due to the large number of cultivars with differences in cycle period (SCHWAB et al., 2019).

It was possible to obtain mean phenology data for each development cycle from experiments performed in Santa Catarina through the thermal sum. The method used to determine the daily thermal sum was: $\mathrm{TSd}=\mathrm{T}_{\text {mean }}-\mathrm{Tb}$, where $T_{\text {mean }}$ is the average daily temperature and $T b$ is the base temperature. For the calculation, three base temperatures were considered, as performed by Uhlmann et al. (2017), being $5^{\circ} \mathrm{C}$ for the sprouting phase, $2^{\circ} \mathrm{C}$ for the vegetative phase and $6^{\circ} \mathrm{C}$ for the reproductive phase of gladiolus. The thermal sum accumulated in the cycle or in a certain phenological phase was calculated through the accumulation of the daily thermal sum. The air temperature data were obtained from meteorological stations, located in each experimental area.

Data from the Epagri/Ciram Meteorological Database were used to calculate the risk factors. The minimum air temperature in the meteorological station was used to calculate frost occurrence frequency. The calculation was performed for different frost intensities: no frost ( $\operatorname{Tmin} \geq 3^{\circ} \mathrm{C}$ ), weak frost $\left(3^{\circ} \mathrm{C}>\operatorname{Tmin} \geq 1^{\circ} \mathrm{C}\right)$, moderate frost $\left(1^{\circ} \mathrm{C}>\mathrm{Tmin} \geq-2^{\circ} \mathrm{C}\right)$ and strong frost (Tmin $<-2^{\circ} \mathrm{C}$ ) (PANDOLFO et al., 2017). This procedure was done for 14 weather stations.

The maximum air temperature was used to calculate the frequency in which temperatures above $34^{\circ} \mathrm{C}$ occur. From the reproductive stage on, this temperature can cause damage to the flower stems, such as petal and sepal burning, which affects product quality (UHLMANN et al., 2017).

The risk of water deficiency was calculated using the water requirement satisfaction index (WRSI):

$$
W R S I=\frac{E T a}{E T c}
$$

ETa is actual crop evapotranspiration $(\mathrm{mm})$ and ETc is potential crop evapotranspiration $(\mathrm{mm})$.

Areas with a WRSI equal to or greater than $0.65($ WRSI $<0.65)$ were considered suitable in at least $80 \%$ of the years (FARIAS et al., 2009). Irrigation is required for lower WRSI values. The WRSI was calculated for each season and phenological stage of the crop, based on 10-year intervals. The daily climatic water balance was calculated and accumulated for the 10-year intervals, for each season. The maximum soil water storage capacity was predetermined according to the soil's physical characteristics (BLAINSKI et al., 2016). This study considered the depth of the root system to be $30 \mathrm{~cm}$ (ALVINO et al., 1998).

It was possible to estimate the risks in Santa Catarina by analyzing the meteorological variables with probability of occurrence greater than $20 \%$ for all the recorded years. The dates when planting should not be done were identified in the mobile phenology window for the 14 evaluated meteorological stations. It was established that if the sprouting or vegetative phase occurred on a date when the risk of severe frost was greater than $20 \%$, that date would not be indicated for planting. It was also established that if the reproductive phase 
occurred on a date when the risk of low intensity frost was greater than $20 \%$ that date would not be indicated for planting.

Multiple regression analysis was used to generate equations to estimate mean planting date values as a function of altitude and geographic coordinates. The importance of the variable in the model was defined by the Stepwise regression analysis, with a significance level of 0.05 . SIG ArcGis 10.6 was used to develop the regression equations from the studied stations. The equations were applied to the entire State of Santa Catarina, using the Shuttle Radar Topographic Mission - SRTM (USGS, 2006) digital elevation model (DEM) as input data.

\section{RESULTS AND DISCUSSION}

The duration of each development phase was counted in terms of thermal time. The crop basal temperatures were considered for each development phase (SHILLO \& SIMCHON, 1973; SHILLO \& HALEVY, 1976; MUTTONI et al., 2017; SCHWAB et al., 2018; UHLMANN et al., 2017). The thermal time varied according to planting date and to different development cycles (Table 2). Regardless of the season, the four cultivar groups were observed. On average, the early group required $147.0^{\circ} \mathrm{C}$ day for phase $\mathrm{S}$ (sprouting), $810.7^{\circ} \mathrm{C}$ day for $\mathrm{V}$ (vegetative) and $382.8^{\circ} \mathrm{C}$ day for phase $\mathrm{R}$ (Reproductive), completing the cycle at $1340.4^{\circ} \mathrm{C}$ day. The late cycle showed the greatest requirement, $1584.2^{\circ} \mathrm{C}$ day, as the development cycle lasts longer for the cultivars in this group. Similar heat sum values were found in the literature for the climatic conditions of Santa Maria, in the State of Rio Grande do Sul, at different planting dates and for different cultivars, ranging from 849.5 to $1112.7^{\circ} \mathrm{C}$ day for the vegetative phase and from 215.7 to $312.5^{\circ} \mathrm{C}$ day for the reproductive phase (STRECK et al., 2012).

Table 2 - Accumulated thermal sum in the sprouting (S); vegetative (V) and reproductive $(R)$ phases for the Early, Intermediate I, Intermediate II and Late gladiolus development cycles in Santa Catarina.

\begin{tabular}{|c|c|c|c|c|c|c|c|c|c|c|c|c|}
\hline \multirow[b]{2}{*}{ EN } & \multicolumn{3}{|c|}{ Early } & \multicolumn{3}{|c|}{ Intermediate I } & \multicolumn{3}{|c|}{ Intermediate II } & \multicolumn{3}{|c|}{ Late } \\
\hline & $\mathbf{S}$ & $\mathbf{v}$ & $\mathbf{R}$ & B & $\mathbf{v}$ & $\mathbf{R}$ & B & $\mathbf{v}$ & $\mathbf{R}$ & B & $\mathbf{v}$ & $\mathbf{R}$ \\
\hline 1 & 146.7 & 796.7 & 378.1 & 157.0 & 941.5 & 303.5 & 146.7 & 915.0 & 385.3 & 135.6 & 1025.4 & 386.0 \\
\hline 2 & 195.2 & 777.0 & 358.0 & 138.3 & 806.9 & 417.8 & 151.1 & 889.6 & 354.7 & 166.1 & 1016.7 & 382.8 \\
\hline 3 & & & & 165.8 & 801.4 & 368.8 & 165.8 & 898.1 & 344.3 & 142.0 & 982.3 & 361.8 \\
\hline 4 & & & & & & & 204.7 & 907.4 & 365.0 & & & \\
\hline 5 & & & & 199.5 & 867.7 & 299.5 & 208.4 & 842.5 & 362.2 & 191.5 & 999.2 & 347.7 \\
\hline 6 & & & & 192.7 & 917.3 & 231.2 & 213.3 & 897.3 & 255.1 & 201.1 & 1007.8 & 297.7 \\
\hline 7 & 114.0 & 799.3 & 340.8 & 122.7 & 927.4 & 272.7 & 149.5 & 983.3 & 259.9 & 147.3 & 1018.2 & 339.9 \\
\hline 8 & 111.8 & 756.3 & 425.5 & 115.3 & 927.4 & 451.2 & 190.3 & 957.1 & 411.0 & 208.1 & 1036.6 & 509.5 \\
\hline 9 & 167.2 & 924.0 & 411.5 & 132.9 & 944.5 & 453.7 & 168.8 & 1064.0 & 441.9 & 211.9 & 1145.5 & 412.0 \\
\hline 10 & & & & & & & 158.4 & 949.5 & 302.6 & & & \\
\hline 11 & & & & & & & 187.9 & 899.5 & 249.2 & & & \\
\hline 12 & & & & & & & 183.9 & 1143.4 & 350.5 & & & \\
\hline 13 & & & & & & & 234.0 & 1129.9 & 337.5 & & & \\
\hline Mean & 147.0 & 810.7 & 382.8 & 153.0 & 891.8 & 349.8 & 181.8 & 959.7 & 339.9 & 175.5 & 1029.0 & 379.7 \\
\hline SD & 31.8 & 58.8 & 31.8 & 29.3 & 55.2 & 79.6 & 26.7 & 91.5 & 57.0 & 29.4 & 46.7 & 58.7 \\
\hline CV (\%) & 21.6 & 7.2 & 8.3 & 19.2 & 6.2 & 22.8 & 14.7 & 9.5 & 16.8 & 16.7 & 4.5 & 15.5 \\
\hline
\end{tabular}

EN: experimental number; SD: standard deviation; CV: coefficient of variation 
Rainfall is regularly distributed in the different regions of Santa Catarina throughout the year but was possible identify periods with high and low rainfall (BAPTISTA \& SEVERO, 2018). Phenomena such as El Niño Southern Oscillation (ENSO) also influence the climatic conditions in several regions and can modify the rainfall regime (POWER \& DELAGE, 2018). WRSI represents the relationship between the actual and maximum crop evapotranspiration, i.e. the environment's ability to supply the crop water requirements. Regarding water stress, gladiolus plants are sensitive to water excess or deficiency and require highly permeable soils. A minimum desirable situation was defined based on crop sensitivity. Given the lack of references for this crop and its sensitivity to water deficiency, it was decided to use the highest WRSI values found in the literature (FARIAS et al., 2001; MAPA, 2019). In Figure 1, it is possible to observe the probability of occurrence of WRSI<0.65 for each ten-year period, in the studied stations.

Rainfall distribution varies between locations over the months (BAPTISTA \& SEVERO, 2018). A study to characterize the annual rainfall rates in the State did not identify locations with defined dry seasons, considering a $75 \%$ probability of rainfall occurrence (COAN et al., 2014). However, there are risks that vary according to different State locations. In São Joaquim, in Mountain Plateau region, water restriction is not an issue and so there is no unfavorable time for planting. The greatest water restriction risk was recorded in Itapiranga, in the Extreme West region, and São José, in the Coastal region. In general, the other studied places have fewer periods of risk greater than $20 \%$ and do not exceed $30 \%$ of the 10 -year restriction period.

The highest percentage of decades with risk greater than $20 \%$ occur over spring and summer period in Caçador, Chapecó, São Miguel do Oeste, Campos Novos, Videira and Itapiranga. Increased air temperatures generate great evaporative and high plant water demand, which drains the soil. In such a situation, the environment is unable to supply the water requirement, causing plant stress (DINESH et al., 2016). This effect is more pronounced in the Extreme West region, where summer is the period with the least rainfall in the year. In São José, in the Coastal region, the greatest water restriction occurs over autumn and winter, while summer is the period with the highest rainfall. Moreover, the lowest annual rainfall accumulations in the State occur in the Coastal region (COAN et al., 2014; BAPTISTA \& SEVERO, 2018).

Although the crop may suffer from excess water, which favors corm rot, induces delayed development cycle and reduces plant growth (PEREIRA et al., 2009; MAZZINI-GUEDES et al., 2017), its highest sensitivity is related to water deficit. Some of the symptoms that can be triggered by water deficit include a shorter development cycle, burned spike tips and reduced growth. Gladiolus proved to be more sensitive to water deficiency during its vegetative development and initial growth (BASTUG et al., 2006; Pereira et al., 2009). The plants remain alive, but lack of water permanently affects their development and the floral stem is not formed. Furthermore, lack of water during the spike phase can cause inflorescence abortion (PEREIRA et al., 2009; PORTO et al., 2014). 

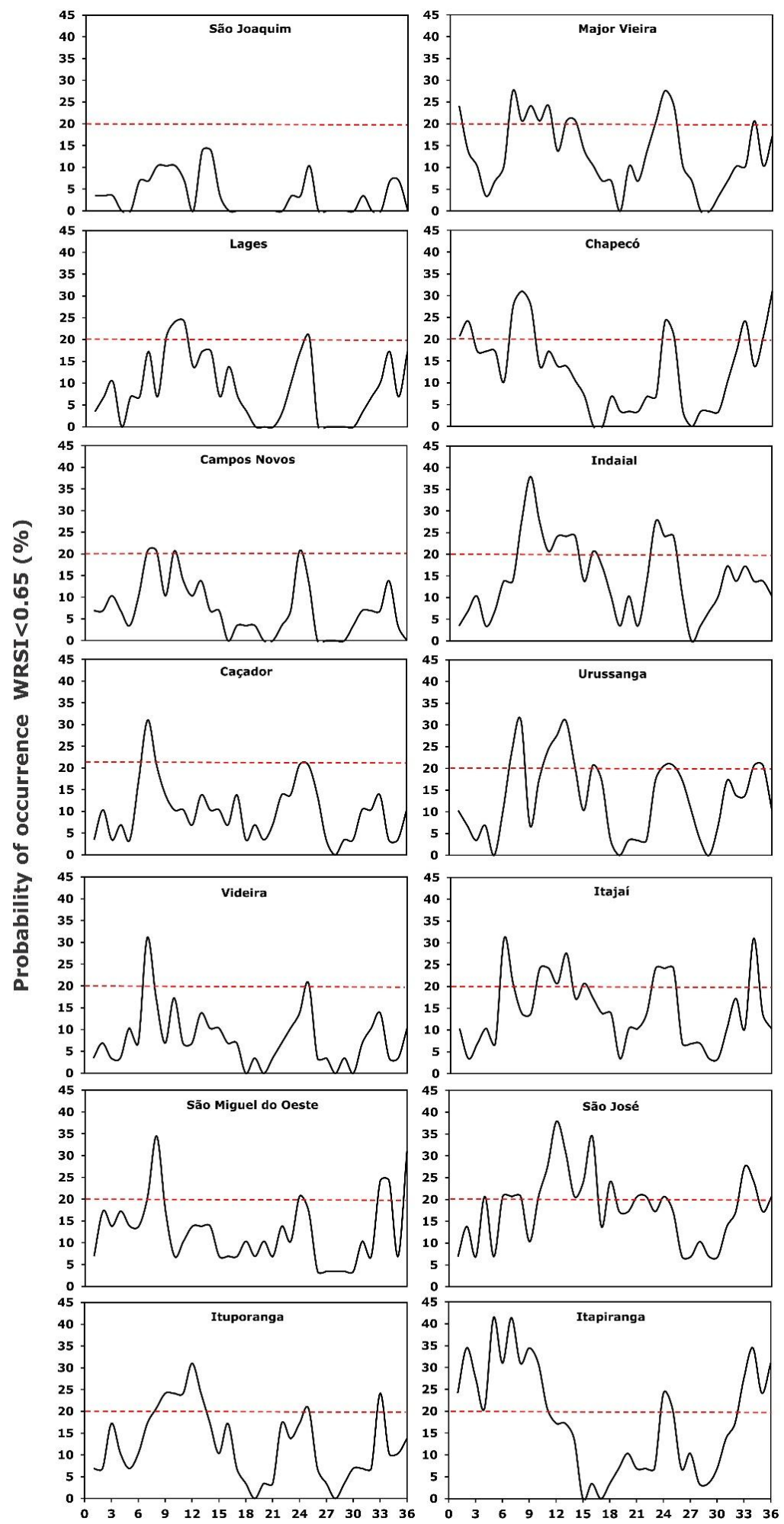

Decennials

Figure 1 - Probability of occurrence of water requirement satisfaction index lower than 0.65 (WRSI<0.65) for each ten-year period in the meteorological stations studied in Santa Catarina. The red dotted line indicates the limit in season considered adequate in $20 \%$ of the years. 
Mazzini-Guedes et al. (2017) observed that when grown in $80 \%$ field capacity, the crop shows reduced development cycle, plants with longer flower stems, greater number of florets and greater diameter. In contrast, plants grown at $25 \%$ field capacity did not produce flower stems, as noted by other authors (PEREIRA et al., 2009; PORTO et al., 2014). The floral stem is formed in the vegetative phase, when the plants undergo initial growth, in the three-leaf stage (SCHWAB et al., 2015). Water deficit in this phase leads the plant to abort floral stem.

Given that the risk of water deficiency over the year has been identified for different locations in Santa Catarina and that irrigation minimizes the risk associated with water deficiency, irrigation is indicated for commercial gladiolus crops. The risk of water deficiency was therefore not considered in the agricultural zoning of climatic risk for the gladiolus crop in Santa Catarina.

Some regions of the State are at high altitudes, where temperatures below or equal to $0^{\circ} \mathrm{C}$ occur, mainly in the months of June and July (WREGE et al., 2018). These low temperatures are limiting for gladiolus, especially during the reproductive phase. The floral stem has great restriction to low temperatures and frost, and both could cause damage that can be irreversible (SCHWAB et al., 2018).

The stations with the lowest planting windows are located above 700 meters altitude: Caçador, Campos Novos, Lages, Major Vieira, São Joaquim and Videira. In these regions, the risk of high and low intensity frost occurrence is greater than $20 \%$ for long periods. The other places are at low altitudes and high temperatures, which reduces the risk of frost. A study by Wrege et al. (2018) showed that frost occurrence correlates with altitude, which confirms the results of this study (Figure 2 ).

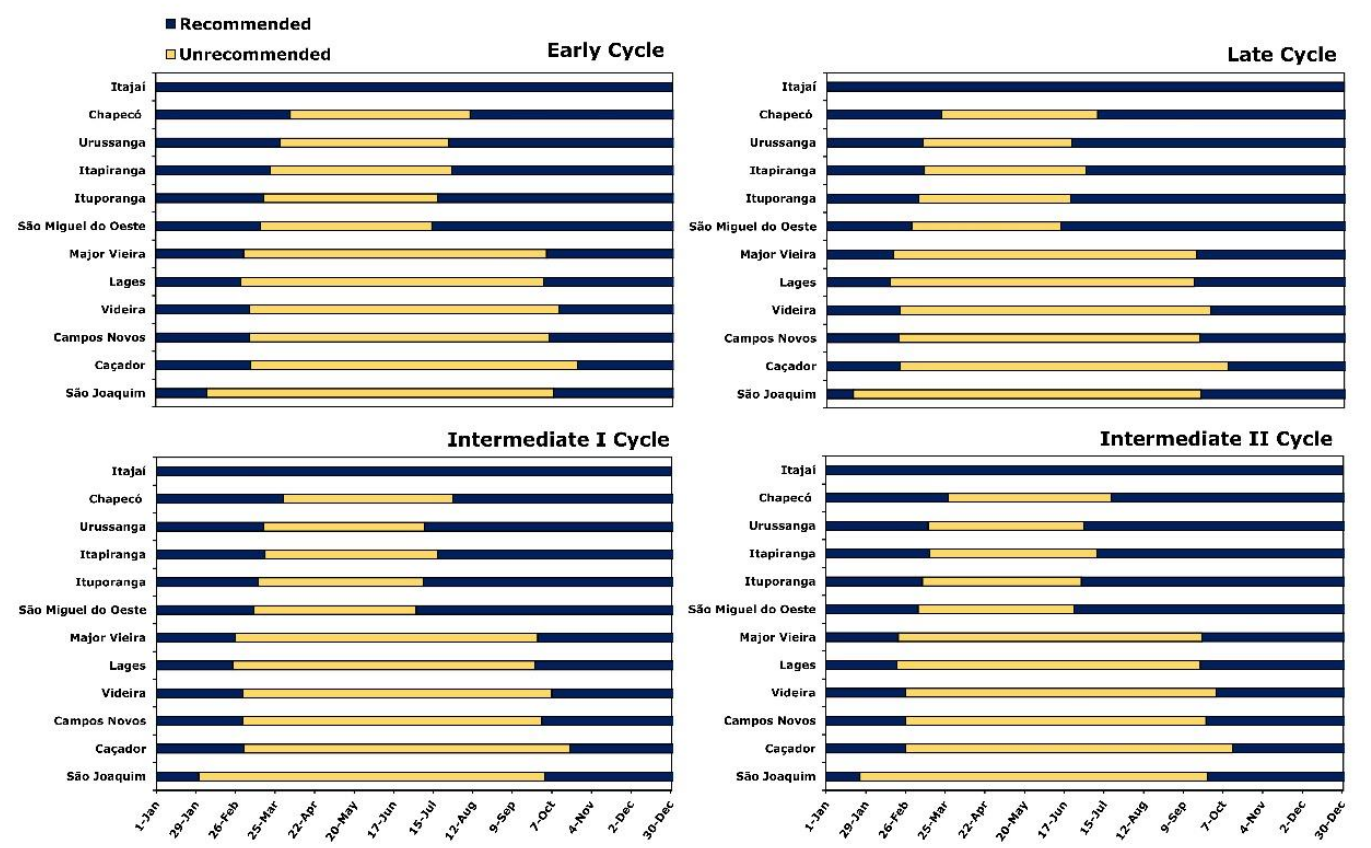

Figure 2 - Recommended and Unrecommended planting period based on the occurrence of strong and low intensity frosts that present a risk for the sprouting, vegetative and reproductive phase in the 12 places studied, for the early, late, intermediate I and II maturation groups. 
In addition, there are climatic differences in the locations above 700 meters of altitude. According to the Köppen classification, Caçador, Campos Novos, Lages, Major Vieira, São Joaquim and Videira show a Cfb type climate humid subtropical with mild summers. The average air temperature in the warmest month is approximately $22^{\circ} \mathrm{C}$. The other places - Itajaí, Chapecó, Urussanga, Itapiranga, Ituporanga and São Miguel do Oeste - show Cfa - humid subtropical climate with mild summers and average temperature above $22^{\circ} \mathrm{C}$. This climate is characteristic of altitudes below 650 meters (ALVARES et al., 2013).

Based on field experiments carried out in Santa Catarina and on the PhenoGlad model that simulates gladiolus development (UHLMANN et al., 2017), it was considered that temperatures equal to or greater than $34^{\circ} \mathrm{C}$ would bring risks to crop development. The method of analysis is air temperature frequency over the analyzed years. Thus, under normal climatic conditions, daily air temperatures of $34^{\circ} \mathrm{C}$ or more do not become a risk to the crop in Santa Catarina (Figure 3). However, the interannual climatic variability can cause conditions where air temperatures reach the study threshold.
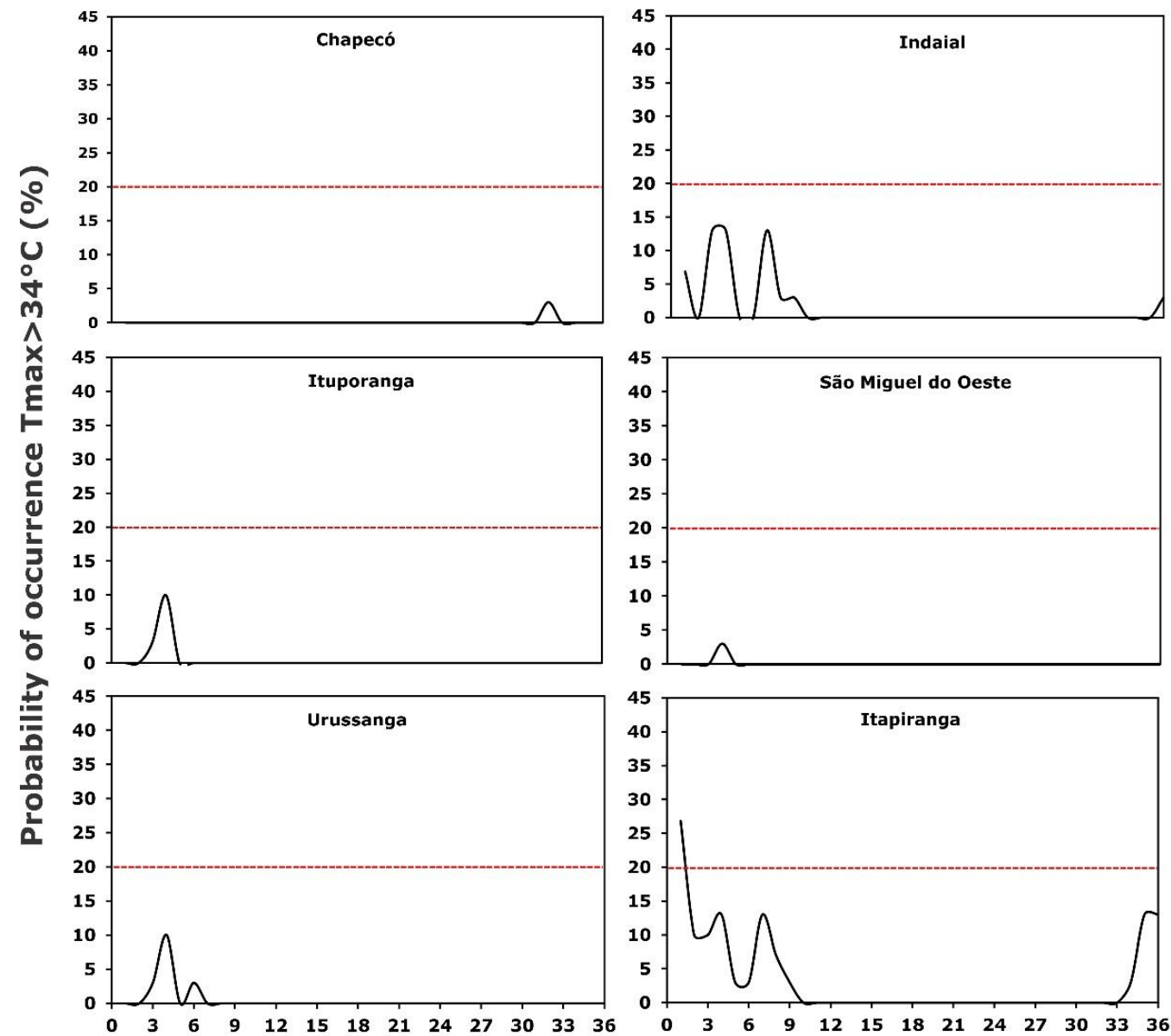

\section{Decennials}

Figure 3 - Probability of occurrence of maximum air temperature equal to or greater than $34^{\circ} \mathrm{C}$, in the meteorological stations studied in Santa Catarina. The red dotted line indicates the limit in season considered adequate in $20 \%$ of the years. 
Multiple regression analysis was used to generate equations (Table 3 ) to estimate mean planting date values as a function of altitude and geographic coordinates and to define the recommended planting time.

Table 3 - Equations used to generate the maps of the Agricultural Climate Risk Zoning for gladiolus in Santa Catarina.

\begin{tabular}{ccc}
\hline Cycle & Equation & $\mathbf{R}^{\mathbf{2}}$ \\
\hline FPC (Early) & $547.4976+8.748164 *$ Long $+0.107908 *$ Alt & 0.721088 \\
FPC (Late) & $610.93333+10.32459 *$ Long $+0.122108 *$ Alt & 0.704811 \\
LPC (Early) & $-88.008-3.46392 *$ Long $-0.02746 *$ Alt & 0.687527 \\
LPC (Late) & $-92.6082-3.34065 *$ Long $-0.03113 *$ Alt & 0.714457 \\
\hline
\end{tabular}

FPC $=$ First possible cultivation date; $\mathrm{LPC}=$ Last possible cultivation date; Long $=$ Longitude; Alt = Altitude.

The maps generated for the different groups of gladiolus maturation show similar periods of restriction. Given that the 10-year period interpolation was used, there is little difference between restricted periods among the groups. For example, in Chapecó (Figure 4) planting is restricted on the following dates: $04 / 05,03 / 31,03 / 27$ and 03/22 for the early, intermediate I and II and late cycle cultivars, respectively. There is only a 10-year period difference for early cultivars, whereas the other cultivars have restrictions over the same 10-year period. It was thus decided to present the zoning for early and late cultivars (Figure 4).

Agricultural Climate Risk Zoning maps (Figure 4) show the dates recommended for gladiolus planting with irrigation in the State of Santa Catarina. Frost is the main risk for the crop considered in this study. Planting dates were classified as unfavorable when the period of frost occurrence is greater than the defined risk or in an intensity just tolerated by the plant.

There is no restriction to gladiolus planting throughout the year in the Coastal region as long as the commercial crops are irrigated. This is due to the low altitudes and to the effect of ocean moisture, which lead to low risk of frosts occurring in this region. South, Midwest, and North regions show the greatest planting restrictions in autumn and winter compared to the West and Extreme West regions. 

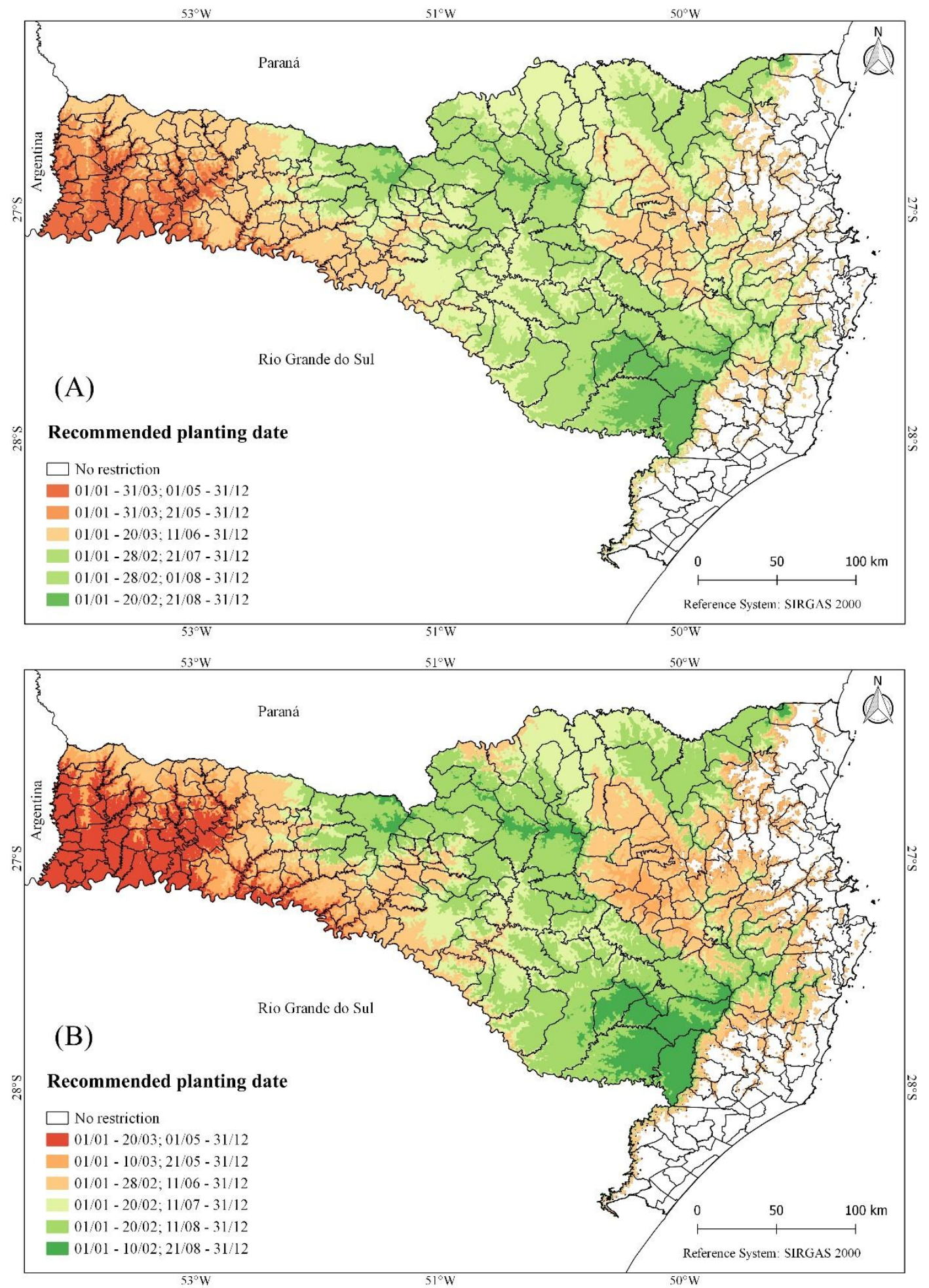

Figure 4 - Agricultural Climate Risk Zoning to early (A) and late (B) cultivars of irrigated gladiolus in Santa Catarina.

Agroclimatic zoning of flowers indicates the periods when planting is recommended throughout the year (CIRAM, 1999) and was developed for Santa 
Catarina considering both the species' bioclimatic requirements, as described in current literature, and climatic conditions. Given the lack of local experimental data, important aspects for gladiolus crop zoning, such as the plant development cycle duration, were not considered in the study of Ciram (1999). Thus, a current Agricultural Climate Risk Zoning for gladiolus offers users more safety and reliability as it is an important agricultural planning tool that aids producers in decision making. This tool indicating the most suitable dates for planting gladiolus in Santa Catarina, reducing the risk of damage to the crop and ensuring product quality. This and other studies that are being undertaken in the State provide support for increasing gladiolus production and make this crop an alternative for diversification and income generation for farmers in Santa Catarina.

\section{CONCLUSIONS}

The main risk associated with gladiolus development is frost occurrence, especially in the Midwest, Mountain and North Plateau regions of Santa Catarina.

Water restriction is most frequently in the Extreme West, West and Coastal regions of the State. Therefore, irrigation is indicated for crop planting in these regions.

Maximum air temperatures that cause damage to the crop are rare, and this risk is considered only for Itapiranga in the Extreme West of Santa Catarina, where using shade screens can minimize the damage caused on flower stems by high temperatures.

Agricultural Climate Risk Zoning shows the potential of gladiolus planting in the State and can be an excellent tool for agricultural planning.

\section{ACKNOWLEDGMENTS}

To the Environmental and Hydrometeorology Information Center of Santa Catarina (CIRAM/ EPAGRI) for meteorological database available. To Foundation for the Support of Research and Innovation in the State of Santa Catarina (FAPESC), University Scholarship Program of Santa Catarina (UNIEDU), Coordination for the Improvement of Higher Education Personnel (CAPES) and Brazilian Research and Technology Council (CNPq) for financial support. To Santa Catarina Federal University (UFSC), Santa Maria Federal University (UFSM) and Santa Catarina Federal Institute (IFC) from Concórdia and Rio do Sul for the institutional partnership and support for research activities.

\section{BIBLIOGRAPHIC REFERENCES}

ALVARES, C.A.; STAPE, J.L.; SENTELHAS, P.C.; GONÇALVEZ, J.L.D.M.; SPAROVEK, G. Köppen's climate classification map for Brazil. Meteorologische Zeitschrift, v.22, p.711-728, 2013. DOI: 10.1127/0941-2948/2013/0507.

ALVINO, A.; ANDRIA, R.; CERIO, L.; MORI, M.; SORRENTINO, G. Physiological response of gladiolus to carbonated water application under two water regimes. Advances in Horticultural Science, v.12, p.145-152, 1998. DOI: http://www.jstor.org/stable/42883202. 
BAPTISTA, G.C.Z.; SEVERO, D.L. Variabilidade espacial e temporal da precipitação de Santa Catarina. Geosul, v.33, p.184-200, 2018. DOI: 10.5007/2177-5230.2018v33n68p184

BASTUG, R.; KARAGUZEL, O.; AYDINSAKIR, K.; BUYUKTAS, D. The effects of drip irrigation on flowering and flower quality of glasshouse gladiolus plant. Agricultural Water Management, v.81, p.132-144, 2006. DOI: 10.1016/j.agwat.2005.04.001

BECKER, C.C.; STRECK, N.A; UHLMANN, L.O.; SILVEIRA, W.B. Scheduling optimum planting window for gladiola based on El Niño Southern Oscillation. Scientia Agricola, v.77, p.1-10, 2020. DOI: 10.1590/1678-992x-2018-0336

BLAINSKI, É.; PANDOLFO, C.; RICCE, W.S.; VEIGA, M.; ARAUJO, C.E.S. Mapeamento da capacidade de água disponível para os solos do estado de Santa Catarina. In: Reunião Brasileira de Manejo e Conservação do Solo e da Água, 20, Foz do Iguaçu, 2016. Anais. Londrina: SBCS, 2016. v. 1. p. 520-522.

BOYLE, R.L.; UCHÔA, S.C.P.; SANTOS, C.S.V. dos; ALVES, J.M.A.; ALBUQUERQUE, J. de A.A. de; MARTINS, S.A. Introdução e avaliação de gladíolos em ambiente de cerrado no Estado de Roraima. Revista Agro@mbiente On-line, v.3, p.36-41, 2009. DOI: 10.18227/1982-8470ragro.v3i1.315.

CIRAM. Zoneamento de Flores. Florianópolis: Epagri, 1999. Available at: < http://www.ciram.epagri.sc.gov.br/index.php?option=com_contenteview=article eid=88eItemid=273 > . Accessed on: 18 Dec. 2019.

COAN, B.D.P.; BACK, A.J.; BONETTI, A.V. Precipitação mensal e anual provável no Estado de Santa Catarina. Revista Brasileira de Climatologia, v.15, p.122142, 2014. DOI: 10.5380/abclima.v15i0.38348.

DINESH, A.; MURALIDHARA, B.; GANGURDE, S.; YOGESHWAR, M. Molecular Response of Plants to Drought, Cold and Heat Stress - A Review. Annual Research e Review in Biology, v.10, p.1-8, 2016. DOI: 10.9734/ARRB/2016/26700

EMBRAPA. Zoneamento Agrícola de Risco Climático: Instrumento de Gestão de Risco Utilizado pelo Seguro Agrícola do Brasil. 2015. Available at: <http://www.agencia.cnptia.embrapa.br/Repositorio/Zoneameno_agricola_000fl 7v6vox02wyiv80ispcrruh04mek.pdf>. Accessed on: 02 Dec. 2019.

FARIAS, J.R.B; NEUMARIER, N.; NEPUMUCENO, A.L. Soja. In: MONTEIRO, J.E.B.A. (Org). Agrometeorologia dos cultivos: o fator meteorológico na produção agrícola. Brasília: Ministério da Agricultura, Pecuária e Abastecimento - Instituto Nacional de Meteorologia, 2009. p.33-149.

LIM, T.K. Gladiolus grandiflorus. In: LIM, T.K. Edible Medicinal and Non Medicinal Plants. New York: Springer, 2014, p.144-150. DOI: 10.1007/978-94017-8748-2_6

MAPA - Ministério da Agricultura Pecuária e Abastecimento. Zoneamento Agrícola de Risco Climático. Available at: $<$ http://indicadores.agricultura.gov.br/zarc/index.htm>. Acessed on: 17 Nov. de 2019.

MAZZINI-GUEDES, R.B.; FILHO, O.G.; BONFIM-SILVA, E.M.; COUTO, J.C.C.; PEREIRA, M.T.J.; SILVA, T.J.A.D. Management of corm size and soil water 
content for gladiolus flower production. Revista Brasileira de Horticultura Ornamental, v.23, p.152-159, 2017. DOI: 10.14295/oh.v23i2.972.

MUTTONI, M.; ALBERTO, C.M.; BARTZ, A.C.; UHLMANN, L.O.; TARTAGLIA, V.D.L.; STRECK, N.A. Cardinal temperatures for planting-emergence phase in gladiolus. Ciência Rural, v.47, e20160824, 2017. DOI: 10.1590/0103$8478 \mathrm{cr} 20160824$.

PANDOLFO, C.; RICCE, W.D.S.; VIANNE, L.F.D.N.; MASSIGNAM, A.M. Zoneamento agroclimático do mirtilo irrigado em Santa Catarina. Revista Agropecuária Catarinense, v.30, p.84-88, 2017. DOI: 10.22491/RAC

PEREIRA, J.R.D.; CARVALHO, J.D.A.; PAIVA, P.D.D.O.; SILVA, D.J.D.; SOUZA, A.M. G.D.; SOUZA, K.J.D. Crescimento e produção de hastes florais de gladíolo cultivado sob diferentes tensões de água no solo. Ciência e Agrotecnologia, v.33, n.4, p.965-970, 2009. DOI: 10.1590/S1413-70542009000400004.

PORTO, R.D.A.; KOETZ, M.; BONFIM-SILVA, E.M.; POLIZEL, A.C.; SILVA, T.J.A.D. Effects of water replacement levels and nitrogen fertilization on growth and production of gladiolus in a greenhouse. Agricultural Water Management, v.131, p.50-56, 2014. DOI: 10.1016/j.agwat.2013.09.007.

POWER, S.B.; F.P. DELAGE, El Niño-Southern Oscillation and Associated Climatic Conditions around the World during the Latter Half of the Twenty-First Century. Journal of Climate, v.31, p.6189-6207, 2018. DOI: 10.1175/JCLI-D18-0138.1

SCHWAB, N.T.; STRECK, N.A.; BECKER, C.C.; LANGNER, J.A.; UHLMANN, L.O.; RIBEIRO, B.S.M.R. A phenological scale for the development of Gladiolus. Annals of Applied Biology, v.166, p.496-507, 2015. DOI: 10.1111/aab.12198.

SCHWAB, N.T.; STRECK, N.A.; UHLMANN, L.O.; BECKER, C.C.; RIBEIRO, B.S.M.R.; LANGNER, J.A.; TOMIOZZO, R. Duration of cycle and injuries due to heat and chilling in gladiolus as a function of planting dates. Revista Brasileira de Horticultura Ornamental, v.24, n.2, p.163-173, 2018. DOI: 10.14295/oh.v24i2.1174.

SCHWAB, N.T.; UHLMANN, L.O.; BECKER, C.C.; TOMIOZZO, R.; STRECK, N.A.; BOSCO, L.C.; BONATTO, M.I.; STANCK, L.T. Gladíolo - Fenologia e manejo para produção de hastes e bulbos. 1.ed. Santa Maria: [S.N.], 2019. 136p.

SHILLO, R., SIMCHON, S. Effect of water content and storage temperature of gladiolus corms on flowering. Scientia Horticulturae, v.1, p.57-62, 1973. DOI: 10.1016/03044238(73)90006X.

SHILLO, R.; HALEVY, A.H. The effects of various environmental factors on flowering of gladiolus. III. Temperature and moisture. Scientia Horticulturae, v.4, p.147-155, 1976. DOI: 10.1016/S03044238(76)800064.

STRECK, N.A.; BELLÉ, R.A.; BACKES, F.A.A.L B.; GABRIEL, L.F.; UHLMANN, L.O.; BECKER, C.C. Desenvolvimento vegetativo e reprodutivo em gladíolo. Ciência Rural, v. 42, p.1968-1974, 2012. DOI: 10.1590/S010384782012001100010.

UHLMANN, L.O.; STRECK, N.A.; BECKER, C.C.; SCHWAB, N.T.; BENEDETTI, R.P.; CHARÃO, A.S.; RIVEIRO, B.S.M.R.; SILVEIRA, W.B.; BACKES, F.A.A.L.; ALBERTO, C.M.; MUTTONI, M.; PAULA, G.M.; TOMIOZZO, R.; BOSCO, L.C.; 
BECKER, D. PhenoGlad: A model for simulating development in Gladiolus. European Journal of Agronomy, v.82, p.33-49, 2017. DOI: 10.1016/j.eja.2016.10.001.

UHLMANN, L.O.; BECKER, C.C.; TOMIOZZO, R.; STRECK, N.A.; SCHONS, A.; BALEST, D.S.; BRAGA, M.S.; SCHWAB, N.T.; LANGNER, J.A. Gladiolus as an alternative for diversification and profit in small rural property. Ornamental Horticulture, v.25, p.200-208, 2019. DOI: 10.14295/oh.v25i2.1541

USGS. Shuttle Radar Topography Mission. 3 Arc Second, Filled Finished 2.0, Global Land Cover Facility. Jet Propulsion Laboratory, California: California Institute of Technology, 2006.

WREGE, M.S.; FRITZSONS, E.; SOARES, M.T.S.; PRELA-PÂNTANO, A.; STEINMETZ, S.; CARAMORI, P.H.; RADIN, B.; PANDOLFO, C. Risco de ocorrência de geada na Região Centro-Sul do Brasil. Revista Brasileira de Climatologia, v.22, p.524-553, 2018. DOI: 10.5380/abclima.v22i0.57306 